\title{
Interindividual Variation in Cardiorespiratory Fitness: A Candidate Gene Study in Han Chinese People
}

\author{
Gaowa ${ }^{1}$, Juan Del Coso ${ }^{2, *}{ }^{-}$, Zhuangzhuang Gu ${ }^{3}$, Wuyun Gerile ${ }^{1}$, Rui Yang ${ }^{4}$, \\ Roberto Díaz-Peña ${ }^{5}$ (D), Pedro L. Valenzuela ${ }^{6}(\mathbb{D})$, Alejandro Lucia ${ }^{7,8}$ and Zihong He ${ }^{4, *}$ \\ 1 Institute of Physical Education, Inner Mongolia Normal University, Huhehaote 010022, China; \\ gaowa@imnu.edu.cn (G.); wygrl@imnu.edu.cn (W.G.) \\ 2 Center for Sport Studies, Rey Juan Carlos University, 28943 Fuenlabrada, Spain \\ 3 Sport Science School, Beijing Sport University, Beijing 100083, China; 2019112049@bsu.edu.cn \\ 4 Biology Center, China Institute of Sport Science, Beijing 100061, China; yangrui@ciss.cn \\ 5 Faculty of Health Sciences, Universidad Autónoma de Chile, Talca 3460000, Chile; roberdp78@gmail.com \\ 6 Department of Systems Biology, University of Alcalá, 28805 Madrid, Spain; pedrol.valenzuela@edu.uah.es \\ 7 Faculty of Sport Sciences, European University of Madrid, 28670 Madrid, Spain; \\ alejandro.lucia@universidadeuropea.es \\ 8 Research Institute Hospital 12 de Octubre ('imas12'), 28041 Madrid, Spain \\ * $\quad$ Correspondence: juan.delcoso@urjc.es (J.D.C.); hezihong@ciss.cn (Z.H.)
}

Received: 1 April 2020; Accepted: 11 May 2020; Published: 15 May 2020

\begin{abstract}
Cardiorespiratory fitness, as assessed through peak oxygen uptake $\left(\mathrm{VO}_{2 \text { peak }}\right)$, is a powerful health indicator. We aimed to evaluate the influence of several candidate causal genetic variants on $\mathrm{VO}_{2 \text { peak }}$ level in untrained Han Chinese people. A total of 1009 participants (566 women; age [mean $\pm \mathrm{SD}$ ] $40 \pm 14$ years, $\mathrm{VO}_{2 \text { peak }} 29.9 \pm 7.1 \mathrm{~mL} / \mathrm{kg} / \mathrm{min}$ ) performed a maximal incremental cycling test for $\mathrm{VO}_{2 \text { peak }}$ determination. Genomic DNA was extracted from peripheral whole blood, and genotyping analysis was performed on 125 gene variants. Using age, sex, and body mass as covariates, and setting a stringent threshold $p$-value of 0.0004 , only one single nucleotide polymorphism (SNP), located in the gene encoding angiotensin-converting enzyme (rs4295), was associated with $\mathrm{VO}_{2 \text { peak }}\left(\beta=0.87 ; p<2.9 \times 10^{-4}\right)$. Stepwise multiple regression analysis identified a panel of three SNPs (rs4295 $=1.1 \%$, angiotensin II receptor type $1 \mathrm{rs} 275652=0.6 \%$, and myostatin rs7570532 $=0.5 \%)$ that together accounted for $2.2 \%(p=0.0007)$ of the interindividual variance in $\mathrm{VO}_{2 \text { peak. }}$ Participants carrying six 'favorable' alleles had a higher $\mathrm{VO}_{2 \text { peak }}(32.3 \pm 8.1 \mathrm{~mL} / \mathrm{kg} / \mathrm{min})$ than those carrying only one favorable allele $(24.6 \pm 5.2 \mathrm{~mL} / \mathrm{kg} / \mathrm{min}, p<0.0001)$. In summary, $\mathrm{VO}_{2 \text { peak }}$ at the pre-trained state is partly influenced by several polymorphic variations in candidate genes, but they represent a minor portion of the variance.
\end{abstract}

Keywords: $\mathrm{VO}_{2 \max }$; maximal oxygen uptake; single nucleotide polymorphism; genomics; endurance performance

\section{Introduction}

Cardiorespiratory fitness (CRF) is positively associated with endurance exercise performance [1] and is a strong prognostic factor of morbidity and mortality from all causes and, particularly, from cardiovascular disease (CVD) [2,3]. While both physical activity (PA) and exercise training can modify CRF and are inversely associated with morbidity and mortality rates [4], CRF per se is a much stronger predictor of prognosis in CVD and metabolic disorders [5,6]. The measure of an individual's peak capacity to perform dynamic aerobic exercise is dependent on the synergistic action of pulmonary, cardiovascular and muscle tissue via a suite of physiological actions that effectively transport and 
deliver oxygen from the atmosphere to mitochondria in working muscles [7,8]. Accordingly, CRF can be assessed by directly measuring the peak oxygen uptake $\left(\mathrm{VO}_{2 \text { peak }}\right)$ reached during a graded dynamic exercise test until exhaustion, involving large muscle masses (e.g., running or bicycling), or by indirectly estimating this variable from the peak workload achieved. Nevertheless, direct evaluation of $\mathrm{VO}_{2 \text { peak }}$ is considered the gold standard measure of CRF and, indeed, the American Heart Association recently advocated for the routine assessment of this measure as a clinical vital sign [9].

$\mathrm{VO}_{2 p e a k}$ is characterized by a high interindividual variability even in people of the same sex, age and with the same level of PA and exercise training. This variability is believed to be related, at least partly, to heredity. A seminal study by Claude Bouchard and colleagues found comparable $\mathrm{VO}_{2 \text { peak }}$ values in brothers of the same sibship, and the similarities in $\mathrm{VO}_{2 \text { peak }}$ were even greater in dizygotic and monozygotic twins [10]. The authors suggested that the genetic effect on $\mathrm{VO}_{2 \text { peak }}$ reached $\sim 40 \%$. In a similar study of 170 individuals and their offspring $(n=259)$, it was found that about $50 \%$ of the interindividual variance in $\mathrm{VO}_{2 \text { peak }}$ corresponded to heritable factors after adjusting for age, sex, body mass, and body composition [11]. These findings have been replicated in subsequent studies with siblings and twins [12] and, to date, it is commonly accepted that $\mathrm{VO}_{2 \text { peak }}$ is influenced by both genetic $(\sim 50-60 \%)$ and environmental factors. It has also been reported that twins with similar $\mathrm{VO}_{2 p e a k}$ values present with comparable levels of a variety of PA indices [13], suggesting that part of the heritability of $\mathrm{VO}_{2 \text { peak }}$ in twins might be due to the similarity of their PA levels. In fact, in a recent analysis of 123,545 single nucleotide polymorphisms (SNPs), only nine were associated with $\mathrm{VO}_{2 \text { peak }}$ [14]. The authors of this study found that those individuals whose genotype was associated with a high $\mathrm{VO}_{2 \text { peak }}$ value had a lower CVD risk (e.g., less visceral fat or lower total blood cholesterol), but they did not calculate the additive effect that the nine SNPs had on the interindividual variability of $\mathrm{VO}_{2 \text { peak }}$. There is therefore controversy on the influence of genetics on $\mathrm{VO}_{2 \text { peak, }}$, which mostly likely stems from the discrepancies between studies conducted on siblings/twins vs those conducted on individuals with no familial connection. In this regard, determining the actual genetic contribution to the interindividual variability in $\mathrm{VO}_{2 \text { peak }}$ would be of major importance to inform how environmental factors-including lifestyle-might contribute to heightened $\mathrm{VO}_{2 \text { peak }}$ values. It is possible that if the influence of genetics on $\mathrm{VO}_{2 \text { peak }}$ is low, exercise training might be a determining factor to enhance 'innate' $\mathrm{VO}_{2 \text { peak }}$ even in those less genetically predisposed, with obvious subsequent benefits for cardiovascular health. Indeed, previous research has reported $\mathrm{VO}_{2 \text { peak }}$ increases of up to $44 \%$ after strenuous training interventions, which would support a strong influence of environmental factors on CRF [15].

Aerobic/endurance exercise-based training appears to be the most effective way to augment $\mathrm{VO}_{2 \text { peak }}$. Exercise training increases rather than decreases the individual differences seen at baseline $\mathrm{VO}_{2 \text { peak }}$ because the response to training itself shows large variation [16]. A genome-wide association study based on 324,611 SNPs found that only 21 SNPs could explain $48.6 \%$ of the change in $\mathrm{VO}_{2 \text { peak }}$ induced by a 20-week exercise training program [17]. Among them, rs6552828, located in the acyl-CoA synthase long-chain member 1 (ACSL1) gene, accounted by itself for $6 \%$ of the training-induced enhancement in $\mathrm{VO}_{\text {peak }}$. In a recent meta-analysis of 35 articles on the genetic influence on $\mathrm{VO}_{2 \text { peak }}$ trainability, a total of 97 genes were associated with this phenotype, although only 13 genetic variants were reproduced by more than two investigations [18].

Knowledge on the genetic influence on baseline $\mathrm{VO}_{2 \text { peak }}$ (i.e., in isolation from training) is mainly based on studies conducted on siblings/twins or in individuals of Caucasian descent, and it remains to be determined whether the genetic variants that might be associated with baseline $\mathrm{VO}_{2 \text { peak }}$ are similar or different in individuals of other ethnicities. Thus, the aim of the present study was to assess the influence of several candidate genetic variants in the interindividual variation of baseline CRF measured as $\mathrm{VO}_{2 \text { peak, }}$ in Han Chinese individuals. 


\section{Materials and Methods}

\subsection{Participants}

A total of 1047 participants (56\% women) volunteered to participate in the study. The sample was recruited from five cities in China: Beijing, Xi'an, Guangzhou, Shenyang, and Tianjin. Inclusion criteria were the following: male/female aged 18-69 years; being of Chinese (Han) descent and unrelated to the other participants; having no CVD, diabetes or abnormal glucose tolerance, or any other acute or chronic disease; and being untrained (i.e., $\leq 2$ sessions/week of $\leq 30 \mathrm{~min}$ of regular physical exercise in the previous 12 months). One week before the start of the investigation, participants were fully informed of the experimental procedures and signed an informed written consent to participate in the investigation. The study protocol was approved by the Institutional Review Board of the China Institute of Sport Science.

\subsection{Experimental Design}

This is an observational cross-sectional study aimed at determining the genetic influence of target genes on the interindividual variability in $\mathrm{VO}_{2 \text { peak }}$ values in untrained Han Chinese individuals. We selected untrained individuals to avoid any influence of exercise training or planned PA in the analysis.

\subsection{Experimental Protocol}

The day of the first experimental trial, participants underwent a medical examination (including medical history and other routine physical examinations) carried out by a licensed physician, to ensure the suitability of all participants to take part in the research protocols. On the same day, whole body dual-energy X-ray absorptiometry (GE Lunar DPX system, Madison, WI, USA) assessments were performed and used to calculate body fat and fat-free mass following previous recommendations [19]. $\mathrm{VO}_{\text {2peak }}$ (in $\mathrm{mL} / \mathrm{kg} / \mathrm{min}$ ) was determined during a continuous incremental exercise test to volitional fatigue performed on a bicycle ergometer (Ergoselect 100, Ergoline GmbH, Bitz, Germany). Before tests, participants were familiarized with the ergometer and with the rating of perceived exertion (RPE), as measured by the Borg 6-20 scale [20]. Participants performed a standardized warm-up (5 min cycling at $20 \mathrm{~W}$ and $60 \mathrm{rpm}$ ), and the workload (starting at $20 \mathrm{~W}$ ) was then increased by $25 \mathrm{~W}$ (men) or $20 \mathrm{~W}$ (women) every 2 minutes until volitional exhaustion. In participants $>60$ years of age, the workload was increased by $20 \mathrm{~W}$ (men) or $15 \mathrm{~W}$ (women) every 2 minutes. During the test, gas exchange data were measured 'breath-by-breath' with a metabolic cart (MetaMax 3B, Cortex Biophysik $\mathrm{GmbH}$, Leipzig, Germany). Certified calibration gases $\left(16.0 \% \mathrm{O}_{2}, 5.0 \% \mathrm{CO}_{2}\right.$, Cortex Biophysik) and a 3-L syringe were used to calibrate the gas analyzer and the flow meter, respectively, before each test. $\mathrm{VO}_{2 \text { peak }}$ was defined as the highest $\mathrm{VO}_{2}$ value (60-s average) obtained during the test. $\mathrm{VO}_{2 \text { peak }}$ was considered valid when participants achieved at least two of the following criteria: (i) $\mathrm{RPE}>17$, (ii) $\mathrm{VO}_{2}$ difference between the last two consecutive loads $<0.15 \mathrm{~L} / \mathrm{min}$, (iii) respiratory exchange ratio $>1.1$, and (iv) peak heart rate $>85 \%$ of the age-adjusted estimate [21]. Heart rate was recorded with a chest strap transmitter (Polar RS400, Polar Electro, Kempele, Finland). The environmental temperature was similar in all measurement centers $\left(\sim 22{ }^{\circ} \mathrm{C}, 40 \%\right.$ relative humidity).

On a different day during the week of testing, genomic DNA was extracted from peripheral whole blood samples using the Wizard Genomic DNA Purification Kit (Promega; Madison, WI, USA). Genotyping was performed at Shanghai Benegene Biotechnology, LTD (Shanghai, China). For analysis, a list of 125 SNPs (Tables A1 and A2, Tables A3 and A4) for the Han population of Beijing, China (CHB) was obtained from the International HapMap Project database. Haplotype-tag SNPs were selected using the following criteria: minor allele frequency $\geq 0.01$ and measure of linkage disequilibrium $\left(r^{2}>0.8\right)$. Initially, genes associated with cardiovascular responses to exercise were chosen, and genes associated with endurance performance, muscle performance, or body composition were then added as all of these factors might contribute to the value of $\mathrm{VO}_{2 \text { peak }}$ (Table 1). 
Table 1. Target genes selected for the investigation.

\begin{tabular}{|c|c|c|c|}
\hline Gene & Numbers of SNPs & Chromosome Location & References \\
\hline$A C E$ & 3 & chr17:58,908,166-58,928,711 & [22] \\
\hline ACE2 & 2 & chrX:15,489,077-15,529,058 & {$[23,24]$} \\
\hline ACSL1 & 15 & chr4: $185,911,544-185,986,209$ & {$[17,25]$} \\
\hline ACTN3 & 1 & $\operatorname{chr11:66,313,866-66,330,800}$ & {$[26,27]$} \\
\hline$A G T$ & 13 & chr1:228,902,892-228,918,564 & {$[28,29]$} \\
\hline AGTR1 & 9 & chr3:149,898,348- $149,943,480$ & {$[30,31]$} \\
\hline AGTR2 & 3 & chrX:115,214,031-115,221,847 & [32] \\
\hline$B D K R B 2$ & 28 & chr14:95,738,950-95,782,536 & [33] \\
\hline$F G F 21$ & 2 & chr19:53,949,156-53,955,394 & [34] \\
\hline FGFR2 & 1 & chr10:123,237,848-123,357,972 & [34] \\
\hline FNDC5 & 3 & chr1:33,327,869-33,338,083 & {$[35]$} \\
\hline FST & 3 & chr5: $52,812,352-52,817,659$ & {$[36,37]$} \\
\hline FTO & 3 & chr16:53,737,875-54,155,853 & {$[38]$} \\
\hline GDF8 & 4 & chr2:190,920,423-190,927,455 & {$[39,40]$} \\
\hline$I L-6$ & 7 & chr7:22,733,345-22,738,141 & [41] \\
\hline$I L-15$ & 2 & chr4:142,557,752-142,665,140 & {$[42,43]$} \\
\hline ITLN1 & 5 & chr1:160,846,329-160,854,960 & {$[44]$} \\
\hline$P G C-1 \alpha$ & 6 & chr4: $23,756,664-23,905,712$ & [45] \\
\hline$P G C-1 \beta$ & 1 & chr5:149,109,861-149,234,585 & [45] \\
\hline PPRC1 & 1 & chr10: $103,880,777-103,902,078$ & [45] \\
\hline PRDM16 & 2 & chr1: $2,985,732-3,355,185$ & [46] \\
\hline PYY & 5 & chr17:39,385,633-39,437,363 & [47] \\
\hline$R E N$ & 5 & chr1: $202,390,571-202,402,088$ & [48] \\
\hline RETN & 1 & $\operatorname{chr} 19: 7,639,972-7,641,340$ & [49] \\
\hline
\end{tabular}

Abbreviations: SNP, single nucleotide polymorphism. Abbreviations for gene names: $A C E$, angiotensin-converting enzyme; ACE2, angiotensin-converting enzyme 2; ACSL1, acyl-CoA synthase long-chain member 1; ACTN3, alpha-actinin-3; $A G T$, angiotensinogen; AGTR1, angiotensin II receptor type 1; AGTR2, angiotensin II receptor type 2; $B D K R B 2$, bradykinin receptor B2; FGF21, Fibroblast growth factor 21; FGFR2, fibroblast growth factor receptor 2; $F N D C 5$, fibronectin type III domain-containing protein 5; FST, follistatin; FTO, fat mass and obesity-associated protein (also known as 'alpha-ketoglutarate-dependent dioxygenase'; GDF8, growth differentiation factor 8 (also known as 'myostatin'); IL-6, interleukin 6; IL-15, interleukin 15; ITLN1, intelectin 1; PGC-1 $\alpha$, peroxisome proliferator-activated receptor-gamma coactivator (PGC)-1alpha; PGC-1 $\beta$, peroxisome proliferator-activated receptor-gamma coactivator (PGC)-1beta; peroxisome PPRC1, proliferator-activated receptor gamma, coactivator-related 1; PRDM16, PR domain containing 16; $P Y Y$, peptide YY; REN, renin; RETN, resistin.

For high-throughput genotyping of SNPs, we used a matrix-assisted laser desorption/ionization time-of-flight mass spectrometry (MALDI-TOF MS) platform (Agena, San Diego, CA, USA). Primers for the polymerase chain reaction (PCR) and single-base extension were designed using the Assay Designer software package (Assay Design Suite V2.0, Agena, San Diego, CA, USA). Genotyping was performed as described elsewhere [50].

\subsection{Statistical Analysis}

All statistical analyses were performed using SAS 9.4 statistical package (SAS institute, Inc., Cary, NC, USA) and PLINK (v1.07). Hardy-Weinberg Equilibrium (HWE) was tested using $\chi^{2}$ tests. Linear regression analyses were conducted to assess the association-expressed as standardized regression coefficients $(\beta)$ - between each $\mathrm{SNP}$ and $\mathrm{VO}_{2 \text { peak, }}$, with age, body mass and sex as covariates. The Bonferroni correction for multiple comparisons was applied to test for statistically significant associations between SNPs and $\mathrm{VO}_{2 \text { peak, }}$, thereby setting the minimum level of significance at $p<0.0004$ (i.e., 0.05 divided by the number of SNPs, i.e., 125). A multivariable regression analysis was then conducted to assess the overall contribution of the most significant SNPs to the interindividual variability of $\mathrm{VO}_{2 \text { peak. }}$. All SNPs with $p<0.05$ were included, and a regression model with backward elimination was used to filter-out redundant SNPs. By using a threshold of 5.0 points in the variance inflation factor, we avoided multicollinearity. SNPs that were retained in the final backward elimination model were then analyzed with a multivariate regression model using forward selection. The produced 
regression equation was accepted at a significance level of $p<0.01$. The values of $\mathrm{R}^{2}$ were adjusted for the number of cases and parameters in the analysis. The relative contribution $\left(\mathrm{R}^{2}\right)$ of each SNP in relation to the explained variance in $\mathrm{VO}_{2 \text { peak }}$ was calculated as follows (Equation (1)):

$$
\text { Partial contribution } \left.\left(\mathrm{R}^{2} \text { adjusted }\right)=([\beta \text { for parameter }] / \Sigma \text { [of all } \beta \text { in equation }]\right),
$$

In the $\mathrm{SNPs}$ retained in multiple regression, $\mathrm{VO}_{2 \text { peak }}$ values were compared among genotypes by using one-way analysis of variance (ANOVA). When the ANOVA showed a significant F value, pairwise differences were assessed using the Tukey post-hoc test. By using the SNPs retained in multiple regression analyses, we calculated a weighted genotype score to assess the combined influence of the SNPs on $\mathrm{VO}_{2 \text { peak }}$ following the procedure of Williams and Folland [51]. First, each genotype was scored within each SNP by assigning 0 arbitrary units (a.u.) to homozygotes for the allele theoretically associated with low $\mathrm{VO}_{2 \text { peak, }} 1$ a.u. to heterozygotes, and 2 a.u. to homozygotes for the allele associated with high $\mathrm{VO}_{2 \text { peak }}$, following an additive model. Each SNP was then weighted by its $\beta$-coefficient (allele effect) based on the assumption that all SNPs of interest have independent effects and contribute in an additive manner to $\mathrm{VO}_{2 \text { peak }}$. Finally, the scores obtained for each SNP were summed to obtain a unique weighted genotype score for each participant (theoretical range: 0-6 a.u.). For clarity, we merged data of participants by using intervals of $1 \mathrm{a}$.u. Differences in $\mathrm{VO}_{2 \text { peak }}$ between participants in the different groups were assessed by one-way analysis of variance and using the least significant difference post hoc test. Finally, the ability of weighted genotype score to distinguish individuals with low or intermediate CRF (i.e., below or above $28 \mathrm{~mL} / \mathrm{kg} / \mathrm{min}$, as proposed by Kodama et al. [52]) was assessed using a receiver operating characteristic (ROC) curve and by determining the area under the ROC curve (AUC).

\section{Results}

Of the initial 1047 individuals recruited, valid $\mathrm{VO}_{2 \text { peak }}$ measurements were obtained for 1009 individuals (566 women), and thus only these participants were included in the analyses. The main characteristics of the participants are shown in Table 2.

Table 2. Main characteristics of the study participants $(\mathrm{N}=1009)$ and their association with peak oxygen uptake.

\begin{tabular}{ccccc}
\hline Variable & Mean \pm SD & Range & $\beta$ & $p$-Value \\
\hline Age (year) & $40 \pm 14$ & $19-69$ & -0.27 & $<0.001$ \\
Height $(\mathrm{cm})$ & $165.3 \pm 8.3$ & $146.2-187.0$ & 0.31 & $<0.001$ \\
Body mass $(\mathrm{kg})$ & $64.3 \pm 11.6$ & $39-104$ & -0.01 & 0.523 \\
Body mass index $\left(\mathrm{kg} / \mathrm{m}^{2}\right)$ & $23.4 \pm 3.1$ & $15.6-34.8$ & -0.64 & $<0.001$ \\
Body fat $(\%)$ & $27.1 \pm 8.8$ & $4.5-44.5$ & -0.58 & $<0.001$ \\
Fat-free mass $(\mathrm{kg})$ & $43.8 \pm 9.5$ & $24.8-70.1$ & 0.31 & $<0.001$ \\
\hline
\end{tabular}

Genotyping was successful (i.e., successful determinations for all SNPs) in 1006 of 1009 participants (99.7\%). From the 125 SNPs analyzed, 10 were discarded because they deviated from HWE (Table A2), 10 because they had a MAF $<5 \%$ (Table A3), and two because only one genotype was detected across the group of participants (Table A4). From the remaining pool of 103 SNPs, only rs4295, located in the angiotensin-converting enzyme $(A C E)$ gene, was significantly associated with $\mathrm{VO}_{2 \text { peak }}\left(p<2.9 \times 10^{-4}\right.$, $\beta=0.87$; minor allele $(G)$ frequency, $38.1 \%$, heterozygosity frequency, $47.4 \%$ ).

Figure 1 shows the distribution of $\mathrm{VO}_{2 \text { peak }}$ values in the study sample. Approximately $2.5 \%$ of all participants had a $\mathrm{VO}_{2 \text { peak }}<20 \mathrm{~mL} / \mathrm{kg} / \mathrm{min}$ and $1.4 \%$ had a $\mathrm{VO}_{2 \text { peak }}$ level $>50 \mathrm{~mL} / \mathrm{kg} / \mathrm{min}$. 


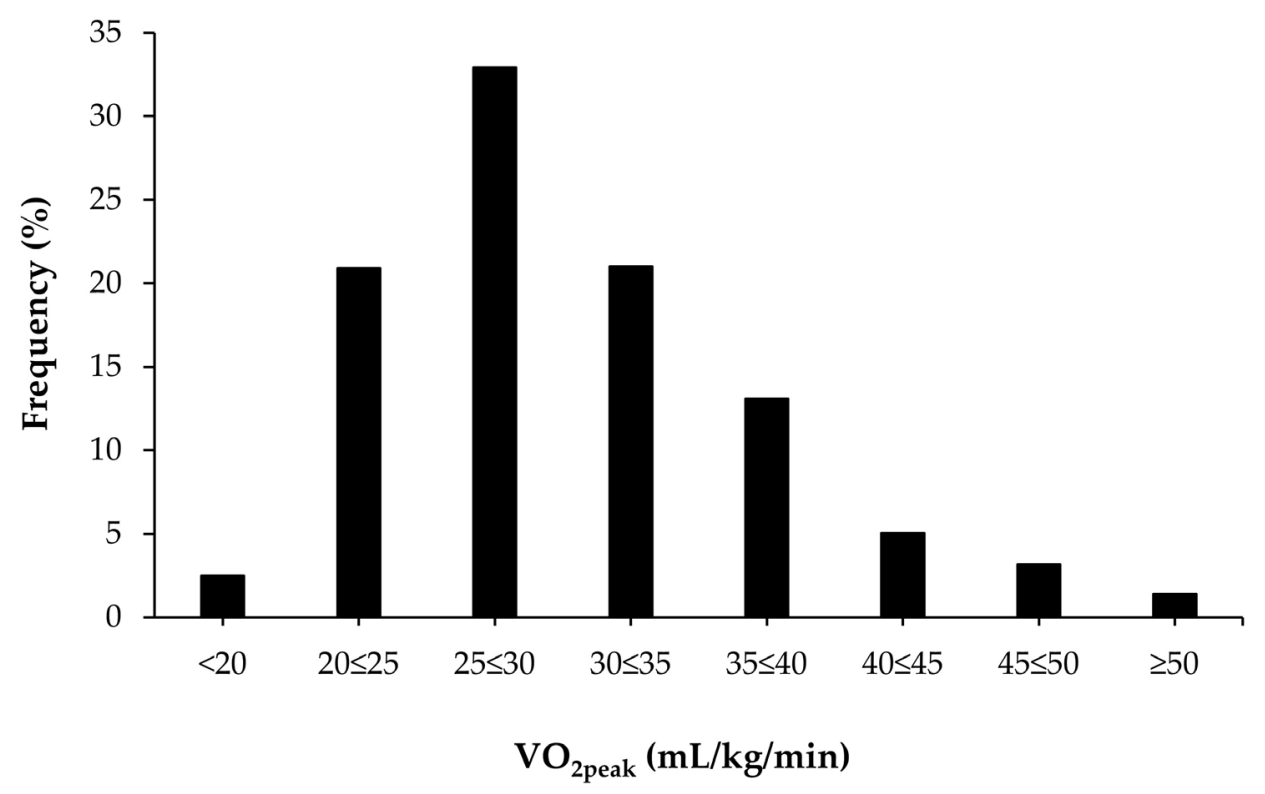

Figure 1. Distribution of peak oxygen uptake $\left(\mathrm{VO}_{2 \text { peak }}\right)$ data in the study participants.

In multiple regression analysis, and after excluding those SNPs with collinearity, only three were retained in the final model (ACE rs4295, AGTR1 rs275652, GDF8 rs7570532), which explained together $2.2 \%(p=0.0007)$ of the variance in $\mathrm{VO}_{2 \text { peak }}$ (Figure 2a, statistical power $\left.=0.987\right)$. The partial contribution of each SNP to the variance in $\mathrm{VO}_{2 \text { peak }}$ is shown in Table 3. The explained variance of $\mathrm{VO}_{2 \text { peak }}$ increased to $50.1 \%(p<0.0001)$ when including covariates such as age, sex and weight in the model (Figure $2 \mathrm{~b}$, statistical power $=1.00$ ).

(a)

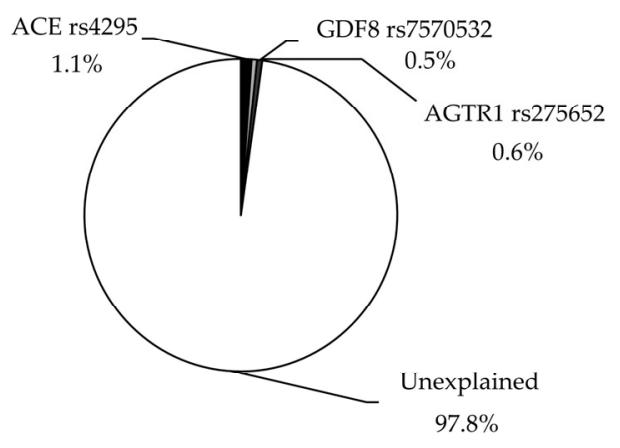

(b)

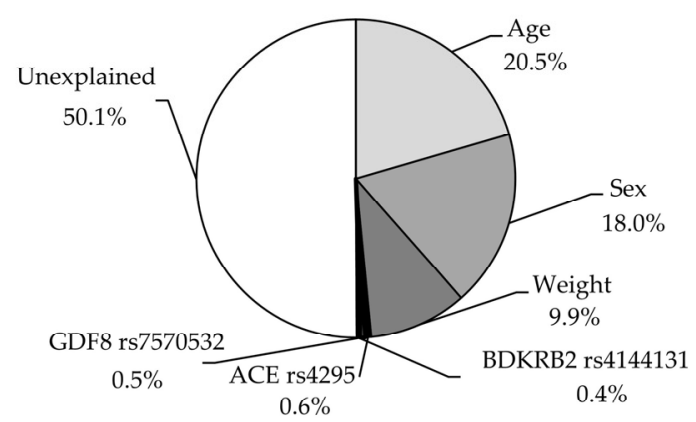

Figure 2. Variance in peak oxygen uptake in the study participants explained by genetic variants alone (a) and by genetic variants plus anthropometric covariates (b). Abbreviations for gene names: $A C E$, angiotensin-converting enzyme; $A G T R 1$, angiotensin II receptor type 1; BDKRB2, bradykinin receptor B2; GDF8, growth differentiation factor 8 (also known as 'myostatin').

Individual $\mathrm{VO}_{2 \text { peak }}$ values for each genotype of the ACE rs4295, AGTR1 rs275652, and GDF8 rs7570532 polymorphisms are shown in Figure 3. The one-way ANOVA revealed statistically significant differences in $A C E$ rs4295 ( $\mathrm{F}=4.95, p=0.007)$ and AGTR1 rs275652 ( $\mathrm{F}=3.90, p=0.021)$ polymorphisms, while the ANOVA did not show differences for GDF8 $\mathrm{rs7570532}(\mathrm{F}=1.64, p=0.194)$ polymorphism. Specifically, GG homozygotes in ACE rs4295 had a mean $\mathrm{VO}_{2 \text { peak }}$ of $31.1 \pm 7.9 \mathrm{~mL} / \mathrm{kg} / \mathrm{min}$, which was higher than that found in heterozygotes (GC, $29.8 \pm 6.9 \mathrm{~mL} / \mathrm{kg} / \mathrm{min} ; p=0.049)$ or in homozygotes for the common allele $(C C, 28.9 \pm 6.7 \mathrm{~mL} / \mathrm{kg} / \mathrm{min} ; p=0.013)$. In addition, AA homozygotes in AGTR1 rs 275652 
had a mean $\mathrm{VO}_{2 \text { peak }}$ of $30.0 \pm 7.3 \mathrm{~mL} / \mathrm{kg} / \mathrm{min}$, which was higher than that found in homozygotes for the minor allele $(C C, 25.5 \pm 5.3 \mathrm{~mL} / \mathrm{kg} / \mathrm{min} ; p=0.024)$.

Table 3. List of single nucleotide polymorphisms associated with peak oxygen uptake in the study participants. Model 1, with genetic-only influence; model 2 with covariates.

\begin{tabular}{cccc}
\hline & SNP & Partial R $^{\mathbf{2}}$ & $p$-Value \\
\hline \multirow{3}{*}{ Model 1 } & ACE rs4295 & 0.0110 & 0.0024 \\
& AGTR1 rs275652 & 0.0056 & 0.0293 \\
GDF8 rs7570532 & 0.0053 & 0.0342 \\
\hline \multirow{3}{*}{ Model 2 } & Age & 0.2052 & $<0.0001$ \\
& Sex & 0.1800 & $<0.0001$ \\
& Weight & 0.0994 & $<0.0001$ \\
& ACE rs4295 & 0.0063 & 0.0015 \\
& GDF8 rs7570532 & 0.0046 & 0.0058 \\
& BDKRB2 rs4144131 & 0.0037 & 0.0135 \\
\hline
\end{tabular}

Abbreviation: SNP, single nucleotide polymorphism; Abbreviations for gene names: $A C E$, angiotensin-converting enzyme; $A G T R 1$, angiotensin II receptor type 1; BDKRB2, bradykinin receptor B2; GDF8, growth differentiation factor 8 (also known as 'myostatin').

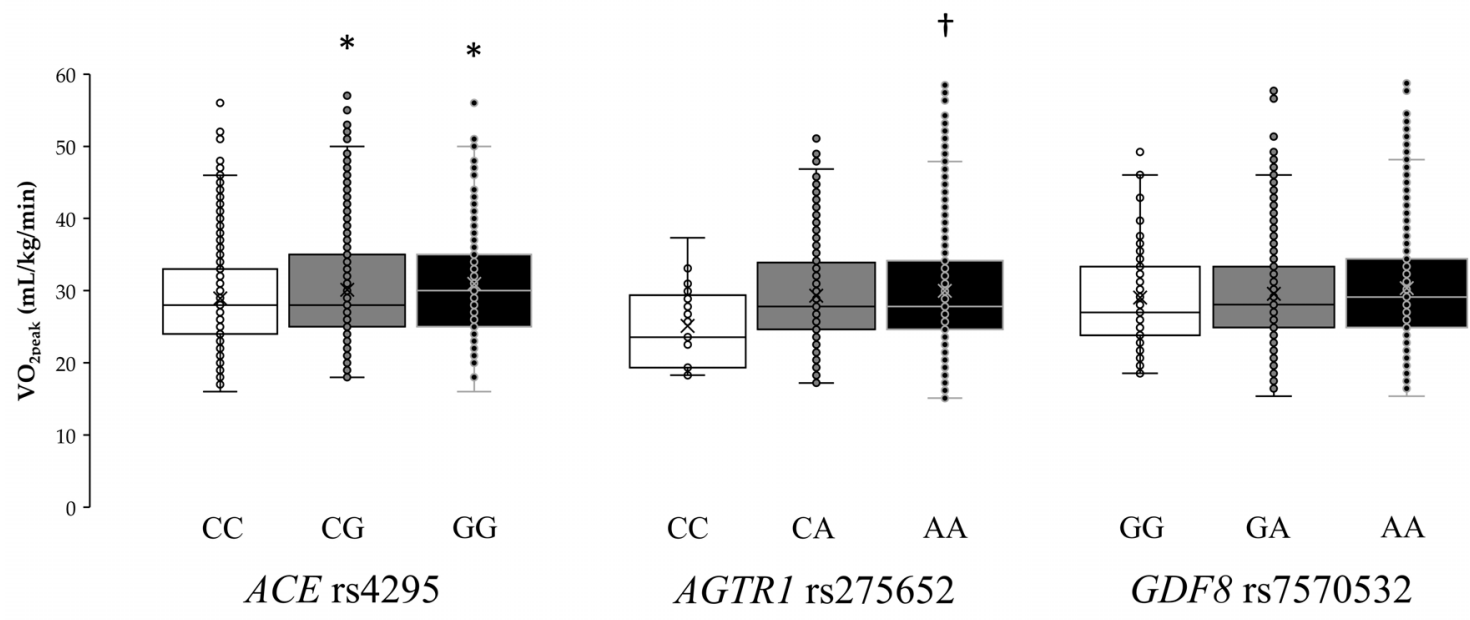

Figure 3. Box-and-whisker plots showing peak oxygen uptake $\left(\mathrm{VO}_{2 \text { peak }}\right)$ in the study participants according to genetic variations in the genes for angiotensin-converting enzyme (ACE; rs4295), angiotensin II receptor type 1 (AGTR1; rs275652), and growth differentiation factor 8 (GDF8, also known as 'myostatin'; rs7570532). The lines in the box represent the first, second (median) and third quartiles, and the whiskers represent $1.5 \times$ interquartile ranges. Each dot represents one individual within the specified genotype. $\left(^{*}\right)$ Depicts a statistically significant difference from CC genotype in ACE rs4295 polymorphism at $p<0.05$. ( $\dagger$ ) Depicts a statistically significant difference from CC genotype in AGTR1 rs275652 polymorphism at $p<0.05$.

A weighted genotype score was constructed using the three SNPs shown in model 1 of genetic-only influence. Participants were categorized with a genotype score from 0 a.u., indicating the presence of homozygosity for all the alleles associated with a lower $\mathrm{VO}_{2 \text { peak }}$ in ACE (rs4295), AGTR1 (rs275652) and GDF8 (rs7570532), to 6 a.u., indicating the presence of homozygosity for all the alleles associated with a higher $\mathrm{VO}_{2 \text { peak }}$ in the aforementioned SNPs. A linear effect was found for genotype score on $\mathrm{VO}_{2 \text { peak }}$ (Figure 4). Specifically, the individuals with 6 a.u. had a higher $\mathrm{VO}_{2 \text { peak }}$ than those with scores up to 4.0 a.u. $(p<0.05)$. In addition, participants with scores $>2$ a.u. had a higher $\mathrm{VO}_{2 \text { peak }}$ than those with scores $<1.0$ a.u. $(p<0.05)$. ROC analysis showed significant discriminatory accuracy of the weighted genotype score in the identification of individuals with low/intermediate CRF $(A U C=0.542)$ with a sensitivity of 0.733 and a specificity of 0.305 . 


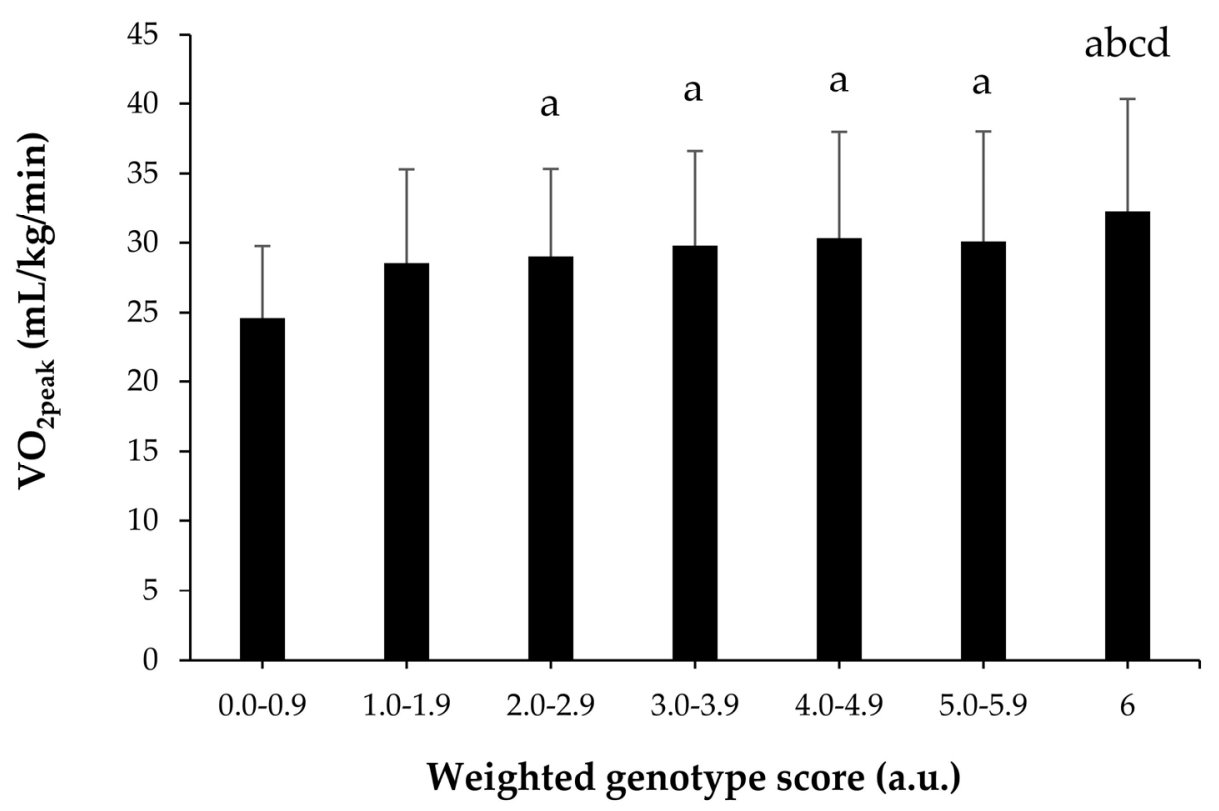

Figure 4. Peak oxygen uptake $\left(\mathrm{VO}_{2 \text { peak }}\right)$ levels in the study participants according to the genotype score (computed by using a weighted score of angiotensin-converting enzyme rs4295, angiotensin II receptor type 1 rs275652 and growth differentiation factor 8 rs7570532 genotypes). Abbreviations/symbols: a.u., arbitrary units; a, difference from $0-0.9$ a.u. at $p<0.05$; b, difference from 1.0-1.9 a.u. at $p<0.05$; c, difference from 2.0-2.9 a.u. at $p<0.05$; d, difference from 3.0-3.9 a.u. at $p<0.05$.

\section{Discussion}

$\mathrm{CRF}$, particularly when objectively determined as $\mathrm{VO}_{2 \text { peak, }}$, is strongly associated with endurance performance and health outcomes. Indeed, $\mathrm{VO}_{2 \text { peak }}$ reflects the peak integrative ability of the organism to deliver oxygen from the atmosphere to the mitochondria of working muscles. The $\mathrm{VO}_{2 \text { peak }}$ is thus determined, among other factors, by peak cardiac output and pulmonary ventilation, lung diffusion capacity, blood and plasma volume, hemoglobin mass, and muscle capillary density and oxidative capacity [53]. Importantly, the mean values of $\mathrm{VO}_{2 \text { peak }}$ of our participants $(29.9 \pm 7.1 \mathrm{~mL} / \mathrm{kg} / \mathrm{min}$ or 8.5 metabolic equivalents, i.e., METs) were barely above the minimum healthy threshold for all-cause and CVD mortality in middle-aged men/women (i.e., 8 METs [52]). It is thus of medical importance to determine whether genetic factors (including specific gene variants) are associated with variability of CRF around (i.e., above vs below) the 8-MET cutoff. Previous research in siblings/twins suggests that $50 \%-60 \%$ of the variance of $\mathrm{VO}_{2 \text { peak }}$ is associated with heredity $[10,12]$. These values seem surprisingly high given the variety of physiological processes and body tissues involved in the uptake and utilization of oxygen in muscle mitochondria. Indeed, there is open debate about the limits of the evidence that support the relative influence of genetics on the variability and trainability of CRF $[54,55]$.

Our findings question the high heritability of $\mathrm{VO}_{2 \text { peak, }}$ at least in Chinese individuals with no familial connection. From the 125 SNPs selected for our study, only one (ACE rs4295) was associated with $\mathrm{VO}_{2 \text { peak }}$. Also, the best model obtained through multiple regression analyses could only explain $\sim 2.2 \%$ of the interindividual variance in $\mathrm{VO}_{2 \text { peak }}$. As in the study by Bye et al. [14], we created a polygenic score to determine whether those individuals with a higher number of alleles associated with $\mathrm{VO}_{2 \text { peak }}$ did indeed present with higher values of this parameter. The only differences found between our findings and those of the Bye et al. study were the number of SNPs included in the polygenic score ( $7 \mathrm{vs} 3$, respectively) and the use of an intermediate genotype score for heterozygotes, which was not included by Bye et al. Interestingly, in both studies, participants with the theoretically lowest (or 'less favorable') genotype scores had the lowest $\mathrm{VO}_{2 \text { peak }}(22-24 \mathrm{~mL} / \mathrm{kg} / \mathrm{min}$ ), which was significantly lower than for those with the theoretically highest (or 'most favorable') genotype score $(\sim 32 \mathrm{~mL} / \mathrm{kg} / \mathrm{min})$. These findings suggest that only a small number of SNPs are associated with the 
odds of having high $\mathrm{VO}_{2 \text { peak }}$ values in untrained individuals. The variance of the interindividual variability in $\mathrm{VO}_{2 \text { peak }}$ explained with these genotypes is low and the addition of favorable alleles might produce a change of $8-10 \mathrm{~mL} / \mathrm{kg} / \mathrm{min}$. This genetic influence might be considerable in clinical terms because each 1-MET (or $3.5 \mathrm{~mL} / \mathrm{kg} / \mathrm{min}$ ) increase in CRF has been shown to confer a $12 \%$ improvement in survival in Caucasian (North-American) men [6]. Moreover, as mentioned above, it is of clinical importance to surpass the 8-MET threshold, and in fact, adults with a CRF clearly above this level ( $>10 \mathrm{METs}$ ) have a remarkably reduced CVD risk [56]. In this regard, the probability of surpassing the 8-MET threshold (equivalent to $28 \mathrm{~mL} / \mathrm{kg} / \mathrm{min}$ ) was doubled in those participants that carried the six 'favorable' alleles (Figure 4).

Only three SNPs were included in the final multiple regression model. ACE rs4295 has not been previously associated with endurance performance, but it is located in the same linkage disequilibrium block as the widely studied ACE insert(I)/deletion(D) polymorphism (rs4340) [57]. The ACE gene encodes angiotensin-converting enzyme and the I allele might be associated with lower circulating levels of enzyme, and the II genotype potentially associated with performance in endurance athletes (odds ratio 1.35; 95\% confidence interval, 1.17 to 1.55 [58]). However, several studies have found no association between the ACE I/D genotype and $\mathrm{VO}_{2 \text { peak }}$ values in trained [59] and untrained [60,61] individuals. With regard to the $A C E$ rs4295 variation found in the present study, although its influence on CRF needs to be replicated in other cohorts, our findings bolster the role of angiotensin-converting enzyme and its coding gene as predictors of CRF-related phenotypes. We also found that carriage of the $\mathrm{C}$ allele in the $A G T R 1$ rs275652 polymorphism was negatively associated with $\mathrm{VO}_{2 \text { peak }}$ values. This gene encodes the angiotensin II receptor $1\left(\mathrm{AT}_{1} \mathrm{R}\right)$, and polymorphisms in AGTR1 have been suggested to be involved in the physiological response to hypoxia [62]. $\mathrm{AT}_{1} \mathrm{R}$ is broadly expressed in different tissues and mediates most of the classical actions of angiotensin II, including vasoconstriction and vascular smooth muscle cell proliferation [63]. Thus, under hypoxic conditions, angiotensin II engages $\mathrm{AT}_{1} \mathrm{R}$ to modulate the pulmonary vasoconstrictive response [64]. Although speculative, it is possible that the $C$ allele in AGTR1 rs275652 might exacerbate pulmonary vasoconstriction during exercise owing to a higher activation of $\mathrm{AT}_{1} \mathrm{R}$ for a given concentration of angiotensin II [65]. The last SNP included in the model explaining $\mathrm{VO}_{2 \text { peak }}$ was rs7570532, a genetic variation in GDF8 encoding myostatin. This and other SNPs in GDF8 have been indirectly associated with a major cardiometabolic condition, obesity [39], but other authors have reported no association of rs7570532 with endurance performance [40]. Myostatin controls the differentiation and proliferation of skeletal muscle throughout embryonic development and regulates muscle growth during adulthood. Mutations in GDF8 that produce non-functional myostatin result in the increased growth of skeletal muscle, demonstrating the existence of a powerful mechanism to control muscle size in normal individuals through this protein [66]. Based on these findings and given the positive association between muscle mass and $\mathrm{VO}_{2 \text { peak }}$ [66-68], it is possible that GDF8 rs7570532 confers a small but significant predisposition to higher $\mathrm{VO}_{2 \text { peak }}$ values. Further research on these three SNPs is clearly warranted.

We acknowledge that the current investigation has some limitations. First, our study sample was heterogeneous in terms of age, sex, and anthropometric characteristics (Table 1). Although we used these variables as covariates in linear regression analyses, the high variability of these variables might have partially influenced our results. In fact, when they were included in multiple regression analyses (Figure $2 \mathrm{~b}$ ), the explained variance of $\mathrm{VO}_{2 \text { peak }}$ increased up to $50.1 \%$. Second, our study only included participants of Han Chinese descent and the results might therefore not be applicable to other ethnicities. Of note, the Han Chinese constitute the world's largest ethnic group (constituting $\sim 18 \%$ of the global population), but further studies in other large ethnic groups will be needed to confirm/discard the generalizability of these results. Lastly, we only analyzed $125 \mathrm{SNPs}$ and thus it is plausible that other candidate genes might have an influence on $\mathrm{VO}_{2 \text { peak }}$. 


\section{Conclusions}

The present study shows that in a cohort of untrained Han Chinese individuals, $\mathrm{VO}_{2 p e a k}$ is influenced by a very few polymorphic variations in key genes even in isolation of training adaptations. The genetic influence accounted for $\sim 2.2 \%$ of the interindividual variance in $\mathrm{VO}_{2 \text { peak, }}$, at least with the 125 SNPs included in this investigation. Although more research is needed, these data suggest that environment, probably more than genetics, is responsible for most of the interindividual variability in $\mathrm{VO}_{2 \text { peak }}$ among healthy Han Chinese adults.

Author Contributions: Conceptualization, Z.H., J.D.C., P.L.V. and A.L.; methodology, Z.H.; formal analysis, Z.H., J.D.C., R.D.-P., and A.L.; assessments G., Z.G., W.G., R.Y.; data curation, Z.H., J.D.C., and A.L.; writing-original draft preparation, Z.H., J.D.C.; writing-review and editing, Z.H., J.D.C., R.D.-P., P.L.V. and A.L.; supervision, A.L.; funding acquisition, Z.H. All authors have read and agreed to the published version of the manuscript.

Funding: This research was funded by key research and development projects of the Ministry of Science and Technology (2018YFF0300402, 2018YFC2000600), China Institute of Sport Science (13-13, 14-08), and projects in the National Science \& Technology Pillar Program during the twelfth Five-year Plan Period (2012BAK23B01). P.L.V is supported by University of Alcalá (FPI2016). Research by A.L. is funded by and the Spanish Ministry of Science and Innovation (Fondo de Investigaciones Sanitarias and Fondos FEDER [grant number PI18/00139]) and Fondos FEDER.

Acknowledgments: The authors would like to thank all the participants in the study.

Conflicts of Interest: The authors declare no conflict of interest. The funders had no role in the design of the study; in the collection, analyses, or interpretation of data; in the writing of the manuscript, or in the decision to publish the results.

\section{Appendix A}

Table A1. List of SNPs investigated for association with $\mathrm{VO}_{2 \text { peak }}(\mathrm{mL} / \mathrm{kg} / \mathrm{min})$ in Han Chinese untrained individuals.

\begin{tabular}{|c|c|c|c|}
\hline Gene & SNP & MA & MAF \\
\hline$A C E$ & rs 4295 & G & 38.1 \\
\hline$A C E$ & rs 4341 & G & 34.9 \\
\hline$A C E$ & rs4363 & $\mathrm{G}$ & 38.7 \\
\hline ACE2 & rs6632677 & $\mathrm{C}$ & 9.2 \\
\hline ACSL1 & rs10022018 & $\mathrm{G}$ & 24.4 \\
\hline ACSL1 & rs11732302 & $\mathrm{C}$ & 24.7 \\
\hline ACSL1 & rs12503643 & G & 45.9 \\
\hline ACSL1 & rs12644905 & $\mathrm{T}$ & 19.6 \\
\hline ACSL1 & rs13126272 & $\mathrm{T}$ & 11.0 \\
\hline ACSL1 & rs1803898 & A & 7.3 \\
\hline ACSL1 & rs2292898 & $\mathrm{C}$ & 7.8 \\
\hline ACSL1 & rs13120078 & A & 8.2 \\
\hline ACSL1 & rs2280297 & $\mathrm{C}$ & 47.6 \\
\hline ACSL1 & rs2292899 & A & 38.1 \\
\hline ACSL1 & rs3749233 & A & 25.9 \\
\hline ACSL1 & rs3792312 & G & 41.7 \\
\hline ACSL1 & rs4069938 & G & 37.7 \\
\hline ACSL1 & rs6552828 & G & 35.2 \\
\hline ACSL1 & rs902177 & $\mathrm{C}$ & 28.2 \\
\hline ACTN3 & rs1815739 & $\mathrm{T}$ & 41.7 \\
\hline$A G T$ & rs10864770 & $\mathrm{T}$ & 34.5 \\
\hline$A G T$ & rs11568046 & C & 12.9 \\
\hline$A G T$ & rs2478523 & $\mathrm{C}$ & 46.0 \\
\hline$A G T$ & rs2478544 & $\mathrm{C}$ & 21.8 \\
\hline$A G T$ & rs2493132 & $\mathrm{T}$ & 37.3 \\
\hline$A G T$ & rs3789671 & G & 45.5 \\
\hline$A G T$ & rs3789678 & $\mathrm{T}$ & 18.7 \\
\hline$A G T$ & rs3889728 & A & 49.4 \\
\hline
\end{tabular}


Table A1. Cont.

\begin{tabular}{|c|c|c|c|}
\hline Gene & SNP & MA & MAF \\
\hline$A G T$ & rs5050 & G & 14.8 \\
\hline$A G T$ & rs6687360 & $\mathrm{C}$ & 33.1 \\
\hline$A G T$ & rs699 & $\mathrm{T}$ & 19.7 \\
\hline$A G T$ & rs7079 & A & 16.2 \\
\hline$A G T$ & rs7536290 & G & 22.0 \\
\hline AGTR1 & rs2131127 & $\mathrm{T}$ & 37.4 \\
\hline AGTR1 & rs275652 & $\mathrm{C}$ & 13.6 \\
\hline AGTR1 & rs3772616 & A & 17.8 \\
\hline AGTR1 & rs385338 & G & 18.0 \\
\hline AGTR1 & rs5182 & $\mathrm{C}$ & 28.1 \\
\hline AGTR1 & rs6801836 & $\mathrm{C}$ & 14.2 \\
\hline$B D K R B 2$ & rs10130005 & $\mathrm{C}$ & 18.3 \\
\hline$B D K R B 2$ & rs10132462 & $\mathrm{T}$ & 28.1 \\
\hline$B D K R B 2$ & rs11160322 & $\mathrm{C}$ & 23.0 \\
\hline$B D K R B 2$ & rs11627176 & G & 12.0 \\
\hline$B D K R B 2$ & rs11627761 & $\mathrm{T}$ & 15.3 \\
\hline$B D K R B 2$ & rs11848502 & $\mathrm{T}$ & 30.1 \\
\hline$B D K R B 2$ & rs12433275 & $\mathrm{T}$ & 16.3 \\
\hline$B D K R B 2$ & rs12888402 & $\mathrm{C}$ & 16.7 \\
\hline$B D K R B 2$ & rs1799722 & $\mathrm{C}$ & 48.0 \\
\hline$B D K R B 2$ & rs1959053 & $\mathrm{T}$ & 25.3 \\
\hline$B D K R B 2$ & rs2069575 & A & 20.4 \\
\hline$B D K R B 2$ & rs2069578 & G & 39.1 \\
\hline$B D K R B 2$ & rs2069586 & $\mathrm{A}$ & 16.5 \\
\hline$B D K R B 2$ & rs2069588 & $\mathrm{T}$ & 18.0 \\
\hline$B D K R B 2$ & rs2369521 & G & 35.6 \\
\hline$B D K R B 2$ & rs4144131 & A & 43.9 \\
\hline$B D K R B 2$ & rs4900315 & $\mathrm{C}$ & 46.5 \\
\hline$B D K R B 2$ & rs4900318 & A & 49.7 \\
\hline$B D K R B 2$ & rs4905470 & A & 20.0 \\
\hline BDKRB2 & rs4905474 & A & 37.1 \\
\hline$B D K R B 2$ & rs6575577 & G & 22.5 \\
\hline$B D K R B 2$ & rs7155797 & $\mathrm{T}$ & 44.4 \\
\hline$B D K R B 2$ & rs7161665 & $\mathrm{C}$ & 47.9 \\
\hline$B D K R B 2$ & rs8013400 & $\mathrm{T}$ & 28.5 \\
\hline$B D K R B 2$ & rs8016905 & A & 32.7 \\
\hline$B D K R B 2$ & rs885818 & $\mathrm{T}$ & 13.4 \\
\hline$B D K R B 2$ & rs945039 & $\mathrm{T}$ & 42.9 \\
\hline FGFR2 & rs2071616 & $\mathrm{T}$ & 8.8 \\
\hline FNDC5 & rs16835198 & $\mathrm{T}$ & 47.7 \\
\hline FNDC5 & rs3480 & G & 24.8 \\
\hline FST & rs3797296 & G & 17.3 \\
\hline$F S T$ & rs3797297 & $\mathrm{T}$ & 12.8 \\
\hline FTO & rs1421085 & $\mathrm{C}$ & 10.4 \\
\hline FTO & rs1558902 & A & 10.6 \\
\hline FTO & rs9939609 & A & 10.4 \\
\hline GDF-8 & rs16832288 & A & 19.9 \\
\hline GDF-8 & rs7570532 & G & 26.0 \\
\hline$I L-15$ & rs1057972 & A & 49.9 \\
\hline$I L-6$ & rs1524107 & $\mathrm{C}$ & 29.3 \\
\hline$I L-6$ & rs2069840 & G & 7.3 \\
\hline$I L-6$ & rs2069830 & G & 27.2 \\
\hline$I L-6$ & rs2069837 & G & 20.1 \\
\hline$I L-6$ & rs2069852 & G & 37.0 \\
\hline ITLN1 & rs2274906 & A & 36.5 \\
\hline
\end{tabular}


Table A1. Cont.

\begin{tabular}{|c|c|c|c|}
\hline Gene & SNP & MA & MAF \\
\hline ITLN1 & rs2274910 & $\mathrm{T}$ & 29.6 \\
\hline ITLN1 & rs2297560 & $\mathrm{T}$ & 13.9 \\
\hline ITLN1 & rs6427552 & $\mathrm{C}$ & 24.7 \\
\hline$P G C-1 \alpha$ & rs12374310 & $\mathrm{C}$ & 43.9 \\
\hline$P G C-1 \alpha$ & rs12650562 & $\mathrm{C}$ & 49.5 \\
\hline$P G C-1 \alpha$ & rs251468 & $\mathrm{T}$ & 19.8 \\
\hline$P G C-1 \alpha$ & rs4452416 & G & 13.4 \\
\hline$P G C-1 \alpha$ & rs4697425 & G & 30.8 \\
\hline$P G C-1 \alpha$ & rs6821591 & $\mathrm{C}$ & 29.9 \\
\hline PRDM16 & rs12409277 & $\mathrm{C}$ & 42.0 \\
\hline PRDM16 & rs2236518 & A & 44.5 \\
\hline PYY & rs10853114 & $\mathrm{C}$ & 37.8 \\
\hline PYY & rs12953033 & A & 6.9 \\
\hline PYY & rs162430 & G & 35.3 \\
\hline PYY & rs1859223 & G & 27.2 \\
\hline$R E N$ & rs11571078 & $\mathrm{T}$ & 12.7 \\
\hline$R E N$ & rs1464816 & $\mathrm{T}$ & 24.4 \\
\hline$R E N$ & rs2368564 & $\mathrm{T}$ & 20.3 \\
\hline$R E N$ & rs4951313 & G & 29.1 \\
\hline$R E N$ & rs5707 & G & 40.3 \\
\hline RETN & rs3745367 & A & 35.5 \\
\hline
\end{tabular}

Abbreviations: MA, minor allele; MAF, minor allele frequency; SNP, single nucleotide polymorphism; $\mathrm{VO}_{2 \text { peak, }}$ peak oxygen uptake. Abbreviations for gene names: $A C E$, angiotensin-converting enzyme; $A C E 2$, angiotensin-converting enzyme 2; ACSL1, acyl-CoA synthase long-chain member 1; ACTN3, alpha-actinin-3; AGT, angiotensinogen; AGTR1, angiotensin II receptor type 1; AGTR2, angiotensin II receptor type 2; BDKRB2, bradykinin receptor B2; FGF21, Fibroblast growth factor 21; FGFR2, fibroblast growth factor receptor 2; FNDC5, fibronectin type III domain-containing protein 5; FST, follistatin; FTO, fat mass and obesity-associated protein (also known as 'alpha-ketoglutarate-dependent dioxygenase'; GDF8, growth differentiation factor 8 (also known as 'myostatin'); IL-6, interleukin 6; IL-15, interleukin 15; ITLN1, intelectin 1; PGC-1 $\alpha$, peroxisome proliferator-activated receptor-gamma coactivator (PGC)-1alpha; PRDM16, PR domain containing 16; PYY, peptide YY; REN, renin; RETN, resistin.

\section{Appendix B}

Table A2. List of SNPs discarded for analyses because did not meet the Hardy-Weinberg equilibrium.

\begin{tabular}{cccc}
\hline Gene & SNP & MA & MAF \\
\hline ACE2 & rs2074192 & $\mathrm{T}$ & 42.6 \\
ACE2 & rs6632677 & $\mathrm{C}$ & 9.2 \\
AGTR1 & $\mathrm{rs} 12721241$ & $\mathrm{~A}$ & 12.0 \\
AGTR1 & $\mathrm{rs} 2675511$ & $\mathrm{G}$ & 13.9 \\
AGTR2 & $\mathrm{rs5193}$ & $\mathrm{T}$ & 15.9 \\
AGTR2 & $\mathrm{rs} 12840631$ & $\mathrm{G}$ & 18.1 \\
AGTR2 & $\mathrm{rs6608590}$ & $\mathrm{T}$ & 41.6 \\
BDKRB2 & $\mathrm{rs} 4900313$ & $\mathrm{~A}$ & 16.2 \\
PGC1 $\beta$ & $\mathrm{rs} 17110586$ & $\mathrm{G}$ & 14.8 \\
PRC & $\mathrm{rs} 17114388$ & $\mathrm{G}$ & 19.7 \\
\hline
\end{tabular}

Abbreviations: see Table A1.

Table A3. List of SNPs discarded for analyses because the frequency of the minor allele was inferior to $5 \%$.

\begin{tabular}{cccc}
\hline Gene & SNP & MA & MAF \\
\hline FGF21 & rs838133 & A & 1.1 \\
FGF21 & rs838145 & G & 1.3 \\
FNDC5 & rs726344 & A & 0.2 \\
\hline
\end{tabular}


Table A3. Cont.

\begin{tabular}{cccc}
\hline Gene & SNP & MA & MAF \\
\hline FST & rs12152850 & T & 1.6 \\
GDF-8 & rs1805086 & $\mathrm{C}$ & 0.2 \\
GDF-8 & rs3791784 & G & 2.3 \\
IL-6 & rs1800795 & $\mathrm{C}$ & 0.7 \\
IL-15 & rs1589241 & $\mathrm{T}$ & 0.8 \\
IL-6 & rs1554606 & $\mathrm{T}$ & 1.8 \\
ITLN1 & rs11265509 & $\mathrm{T}$ & 4.7 \\
\hline
\end{tabular}

Abbreviations: see Table A1.

Table A4. List of SNPs discarded for analyses because all individuals of the sample had the same genotype.

\begin{tabular}{ccc}
\hline Gene & SNP & Genotype \\
\hline AGTR1 & rs12721276 & CC \\
PYY & rs432747 & GG \\
\hline
\end{tabular}

Abbreviations: see Table A1.

\section{References}

1. Joyner, M.J.; Coyle, E.F. Endurance exercise performance: The physiology of champions. J. Physiol. 2008, 586, 35-44. [CrossRef]

2. Fletcher, G.F.; Landolfo, C.; Niebauer, J.; Ozemek, C.; Arena, R.; Lavie, C.J. Promoting Physical Activity and Exercise: JACC Health Promotion Series. J. Am. Coll. Cardiol. 2018, 72, 1622-1639. [CrossRef]

3. Lavie, C.J.; Ozemek, C.; Carbone, S.; Katzmarzyk, P.T.; Blair, S.N. Sedentary Behavior, Exercise, and Cardiovascular Health. Circ. Res. 2019, 124, 799-815. [CrossRef]

4. Lavie, C.J.; Carbone, S.; Kachur, S.; O'keefe, E.L.; Elagizi, A. Effects of Physical Activity, Exercise, and Fitness on Obesity-Related Morbidity and Mortality. Curr. Sports Med. Rep. 2019, 18, 292-298. [CrossRef]

5. Harber, M.P.; Kaminsky, L.A.; Arena, R.; Blair, S.N.; Franklin, B.A.; Myers, J.; Ross, R. Impact of Cardiorespiratory Fitness on All-Cause and Disease-Specific Mortality: Advances Since 2009. Prog. Cardiovasc. Dis. 2017, 60, 11-20. [CrossRef]

6. Myers, J.; Prakash, M.; Froelicher, V.; Do, D.; Partington, S.; Edwin Atwood, J. Exercise capacity and mortality among men referred for exercise testing. N. Engl. J. Med. 2002, 346, 793-801. [CrossRef] [PubMed]

7. Ozemek, C.; Laddu, D.R.; Lavie, C.J.; Claeys, H.; Kaminsky, L.A.; Ross, R.; Wisloff, U.; Arena, R.; Blair, S.N. An Update on the Role of Cardiorespiratory Fitness, Structured Exercise and Lifestyle Physical Activity in Preventing Cardiovascular Disease and Health Risk. Prog. Cardiovasc. Dis. 2018, 61, 484-490. [CrossRef] [PubMed]

8. Valenzuela, P.L.; Maffiuletti, N.A.; Joyner, M.J.; Lucia, A.; Lepers, R. Lifelong Endurance Exercise as a Countermeasure Against Age-Related VO2max Decline: Physiological Overview and Insights from Masters Athletes. Sport. Med. 2019, 50.

9. Ross, R.; Blair, S.N.; Arena, R.; Church, T.S.; Després, J.P.; Franklin, B.A.; Haskell, W.L.; Kaminsky, L.A.; Levine, B.D.; Lavie, C.J.; et al. Importance of Assessing Cardiorespiratory Fitness in Clinical Practice: A Case for Fitness as a Clinical Vital Sign: A Scientific Statement from the American Heart Association. Circulation 2016, 134, e653-e699. [CrossRef]

10. Bouchard, C.; Lesage, R.; Lortie, G.; Simoneau, J.A.; Hamel, P.; Boulay, M.R.; Pérusse, L.; Thériault, G.; Leblanc, C. Aerobic performance in brothers, dizygotic and monozygotic twins. Med. Sci. Sports Exerc. 1986, 18, 639-646. [CrossRef]

11. Bouchard, C.; Warwick Daw, E.; Rice, T.; Pérusse, L.; Gagnon, J.; Province, M.A.; Leon, A.S.; Rao, D.C.; Skinner, J.S.; Wilmore, J.H. Familial resemblance for $\mathrm{VO}(2 \mathrm{max})$ in the sedentary state: The HERITAHE family study. Med. Sci. Sports Exerc. 1998, 30, 252-258. [CrossRef] 
12. Schutte, N.M.; Nederend, I.; Hudziak, J.J.; Bartels, M.; de Geus, E.J.C. Twin-sibling study and meta-analysis on the heritability of maximal oxygen consumption. Physiol. Genomics 2016, 48, 210-219. [CrossRef]

13. Mustelin, L.; Latvala, A.; Pietiläinen, K.H.; Piirilä, P.; Sovijärvi, A.R.; Kujala, U.M.; Rissanen, A.; Kaprio, J. Associations between sports participation, cardiorespiratory fitness, and adiposity in young adult twins. J. Appl. Physiol. 2011, 110, 681-686. [CrossRef]

14. Bye, A.; Klevjer, M.; Ryeng, E.; da Silva, G.J.J.; Moreira, J.B.N.; Stensvold, D.; Wisløff, U. Identification of novel genetic variants associated with cardiorespiratory fitness. Prog. Cardiovasc. Dis. 2020. [CrossRef]

15. Hickson, R.C.; Bomze, H.A.; Holloszy, J.O. Linear increase in aerobic power induced by a strenuous program of endurance exercise. J. Appl. Physiol. Respir. Environ. Exerc. Physiol. 1977, 42, 372-376. [CrossRef]

16. Bouchard, C.; Rankinen, T. Individual differences in response to regular physical activity. Med. Sci. Sports Exerc. 2001, 33. [CrossRef]

17. Bouchard, C.; Sarzynski, M.A.; Rice, T.K.; Kraus, W.E.; Church, T.S.; Sung, Y.J.; Rao, D.C.; Rankinen, T. Genomic predictors of the maximal $\mathrm{O} 2$ uptake response to standardized exercise training programs. J. Appl. Physiol. 2011, 110, 1160-1170. [CrossRef]

18. Williams, C.J.; Williams, M.G.; Eynon, N.; Ashton, K.J.; Little, J.P.; Wisloff, U.; Coombes, J.S. Genes to predict VO2max trainability: A systematic review. BMC Genomics 2017, 18, 831. [CrossRef]

19. Shepherd, J.A.; Ng, B.K.; Sommer, M.J.; Heymsfield, S.B. Body composition by DXA. Bone 2017, 104, $101-105$. [CrossRef]

20. Borg, G. Psychophysical scaling with applications in physical work and the perception of exertion. Scand. J. Work. Environ. Heal. 1990, 16, 55-58. [CrossRef]

21. Edvardsen, E.; Hem, E.; Anderssen, S.A. End criteria for reaching maximal oxygen uptake must be strict and adjusted to sex and age: A cross-sectional study. PLoS ONE 2014, 9, e85276. [CrossRef]

22. Puthucheary, Z.; Skipworth, J.R.A.; Rawal, J.; Loosemore, M.; Van Someren, K.; Montgomery, H.E. The ACE gene and human performance: 12 Years on. Sport. Med. 2011, 41, 433-448. [CrossRef]

23. Chen, Y.Y.; Zhang, P.; Zhou, X.M.; Liu, D.; Zhong, J.C.; Zhang, C.J.; Jin, L.J.; Yu, H.M. Relationship between genetic variants of ACE2 gene and circulating levels of ACE2 and its metabolites. J. Clin. Pharm. Ther. 2018, 43, 189-195. [CrossRef]

24. Wang, S.; Fu, C.; Zou, Y.; Wang, H.; Shi, Y.; Xu, X.; Chen, J.; Song, X.; Huan, T.; Hui, R. Polymorphisms of angiotensin-converting enzyme 2 gene associated with magnitude of left ventricular hypertrophy in male patients with hypertrophic cardiomyopathy. Chin. Med. J. (Engl). 2008, 121, 27-31. [CrossRef]

25. Yvert, T.; He, Z.-H.; Santiago, C.; Hu, Y.; Li, Y.-C.; Gómez-Gallego, F.; Fiuza-Luces, C.; Verde, Z.; Muniesa, C.A.; Oliván, J.; et al. Acyl coenzyme A synthetase long-chain 1 (ACSL1) gene polymorphism (rs6552828) and elite endurance athletic status: A replication study. PLoS ONE 2012, 7, e41268. [CrossRef]

26. Del Coso, J.; Hiam, D.; Houweling, P.; Pérez, L.M.; Eynon, N.; Lucía, A. More than a 'speed gene': ACTN3 R577X genotype, trainability, muscle damage, and the risk for injuries. Eur. J. Appl. Physiol. 2019, 119, 49-60. [CrossRef]

27. Del Coso, J.; Moreno, V.; Gutiérrez-Hellín, J.; Baltazar-Martins, G.; Ruíz-Moreno, C.; Aguilar-Navarro, M.; Lara, B.; Lucía, A. ACTN3 R577X genotype and exercise phenotypes in recreational marathon runners. Genes (Basel) 2019, 10, 413. [CrossRef]

28. Takakura, Y.; Yoshida, T.; Yoshioka, K.; Umekawa, T.; Kogure, A.; Toda, H.; Kagawa, K.; Fukui, S.; Yoshikawa, T. Angiotensinogen gene polymorphism (Met235Thr) influences visceral obesity and insulin resistance in obese Japanese women. Metabolism 2006, 55, 819-824. [CrossRef]

29. Purkait, P.; Halder, K.; Thakur, S.; Ghosh Roy, A.; Raychaudhuri, P.; Bhattacharya, S.; Sarkar, B.N.; Naidu, J.M. Association of angiotensinogen gene SNPs and haplotypes with risk of hypertension in eastern Indian population. Clin. Hypertens. 2017, 23, 12. [CrossRef]

30. Rico-Sanz, J.; Rankinen, T.; Rice, T.; Leon, A.S.; Skinner, J.S.; Wilmore, J.H.; Rao, D.C.; Bouchard, C. Quantitative trait loci for maximal exercise capacity phenotypes and their responses to training in the HERITAGE Family Study. Physiol. Genomics 2004, 16, 256-260. [CrossRef]

31. Carey, R.M.; Siragy, H.M. Newly recognized components of the renin-angiotensin system: Potential roles in cardiovascular and renal regulation. Endocr. Rev. 2003, 24, 261-271. [CrossRef]

32. Dietze, G.J.; Henriksen, E.J. Angiotensin-converting enzyme in skeletal muscle: Sentinel of blood pressure control and glucose homeostasis. J. Renin. Angiotensin. Aldosterone. Syst. 2008, 9, 75-88. [CrossRef] 
33. Brull, D.; Dhamrait, S.; Myerson, S.; Erdmann, J.; Regitz-Zagrosek, V.; World, M.; Pennell, D.; Humphries, S.E.; Montgomery, H. Bradykinin B2BKR receptor polymorphism and left-ventricular growth response. Lancet 2001, 358, 1155-1156. [CrossRef]

34. Kaess, B.M.; Barnes, T.A.; Stark, K.; Charchar, F.J.; Waterworth, D.; Song, K.; Wang, W.Y.S.; Vollenweider, P.; Waeber, G.; Mooser, V.; et al. FGF21 signalling pathway and metabolic traits-genetic association analysis. Eur. J. Hum. Genet. 2010, 18, 1344-1348. [CrossRef]

35. Novelle, M.G.; Contreras, C.; Romero-Picó, A.; López, M.; Diéguez, C. Irisin, two years later. Int. J. Endocrinol. 2013, 2013. [CrossRef]

36. Pedersen, B.K. A muscular twist on the fate of fat. N. Engl. J. Med. 2012, 366, 1544-1545. [CrossRef]

37. Vamvini, M.T.; Aronis, K.N.; Panagiotou, G.; Huh, J.Y.; Chamberland, J.P.; Brinkoetter, M.T.; Petrou, M.; Christophi, C.A.; Kales, S.N.; Christiani, D.C.; et al. Irisin mRNA and circulating levels in relation to other myokines in healthy and morbidly obese humans. Eur. J. Endocrinol. 2013, 169, 829-834. [CrossRef]

38. Liu, A.L.; Xie, H.J.; Xie, H.Y.; Liu, J.; Yin, J.; Hu, J.S.; Peng, C.Y. Association between fat mass and obesity associated (FTO) gene rs9939609 A/T polymorphism and polycystic ovary syndrome: A systematic review and meta-analysis. BMC Med. Genet. 2017, 18, 89. [CrossRef]

39. Pan, H.; Ping, X.C.; Zhu, H.J.; Gong, F.Y.; Dong, C.X.; Li, N.S.; Wang, L.J.; Yang, H.B. Association of myostatin gene polymorphisms with obesity in Chinese north Han human subjects. Gene 2012, 494, 237-241. [CrossRef]

40. Döring, F.; Onur, S.; Kürbitz, C.; Boulay, M.R.; Pérusse, L.; Rankinen, T.; Rauramaa, R.; Wolfarth, B.; Bouchard, C. Single nucleotide polymorphisms in the myostatin (MSTN) and muscle creatine kinase (CKM) genes are not associated with elite endurance performance. Scand. J. Med. Sci. Sport. 2011, 21, 841-845. [CrossRef]

41. Harvey, N.R.; Voisin, S.; Dunn, P.J.; Sutherland, H.; Yan, X.; Jacques, M.; Papadimitriou, I.D.; Haseler, L.J.; Ashton, K.J.; Haupt, L.M.; et al. Genetic variants associated with exercise performance in both moderately trained and highly trained individuals. Mol. Genet. Genomics 2020, 295, 515-523. [CrossRef] [PubMed]

42. Riechman, S.E.; Balasekaran, G.; Roth, S.M.; Ferrell, R.E. Association of interleukin-15 protein and interleukin-15 receptor genetic variation with resistance exercise training responses. J. Appl. Physiol. 2004, 97, 2214-2219. [CrossRef] [PubMed]

43. Nielsen, A.R.; Mounier, R.; Plomgaard, P.; Mortensen, O.H.; Penkowa, M.; Speerschneider, T.; Pilegaard, H.; Pedersen, B.K. Expression of interleukin-15 in human skeletal muscle effect of exercise and muscle fibre type composition. J. Physiol. 2007, 584, 305-312. [CrossRef] [PubMed]

44. Huang, C.-J.; Slusher, A.L.; Whitehurst, M.; Wells, M.; Maharaj, A.; Shibata, Y. The impact of acute aerobic exercise on chitinase 3-like protein 1 and intelectin-1 expression in obesity. Exp. Biol. Med. 2016, 241, $216-221$. [CrossRef]

45. He, Z.-H.; Hu, Y.; Li, Y.-C.; Gong, L.-J.; Cieszczyk, P.; Maciejewska-Karlowska, A.; Leonska-Duniec, A.; Muniesa, C.A.; Marín-Peiro, M.; Santiago, C.; et al. PGC-related gene variants and elite endurance athletic status in a Chinese cohort: A functional study. Scand. J. Med. Sci. Sports 2015, 25, 184-195. [CrossRef]

46. Urano, T.; Shiraki, M.; Sasaki, N.; Ouchi, Y.; Inoue, S. Large-scale analysis reveals a functional single-nucleotide polymorphism in the 5'-flanking region of PRDM16 gene associated with lean body mass. Aging Cell 2014, 13, 739-743. [CrossRef]

47. Schubert, M.M.; Sabapathy, S.; Leveritt, M.; Desbrow, B. Acute exercise and hormones related to appetite regulation: A meta-analysis. Sports Med. 2014, 44, 387-403. [CrossRef]

48. Gu, D.; Kelly, T.N.; Hixson, J.E.; Chen, J.; Liu, D.; Chen, J.; Rao, D.C.; Mu, J.; Ma, J.; Jaquish, C.E.; et al. Genetic variants in the renin-angiotensin-aldosterone system and salt sensitivity of blood pressure. J. Hypertens. 2010, 28, 1210-1220. [CrossRef]

49. Bouchard, L.; Weisnagel, S.J.; Engert, J.C.; Hudson, T.J.; Bouchard, C.; Vohl, M.C.; Pérusse, L. Human resistin gene polymorphism is associated with visceral obesity and fasting and oral glucose stimulated C-peptide in the Québec Family Study. J. Endocrinol. Invest. 2004, 27, 1003-1009. [CrossRef]

50. He, Z.-H.; Hu, Y.; Li, Y.-C.; Yvert, T.; Santiago, C.; Gómez-Gallego, F.; Ruiz, J.R.; Lucia, A. Are calcineurin genes associated with athletic status? A function, replication study. Med. Sci. Sports Exerc. 2011, 43, 1433-1440. [CrossRef]

51. Williams, A.G.; Folland, J.P. Similarity of polygenic profiles limits the potential for elite human physical performance. J. Physiol. 2008, 586, 113-121. [CrossRef] [PubMed] 
52. Kodama, S.; Saito, K.; Tanaka, S.; Maki, M.; Yachi, Y.; Asumi, M.; Sugawara, A.; Totsuka, K.; Shimano, H.; Ohashi, Y.; et al. Cardiorespiratory fitness as a quantitative predictor of all-cause mortality and cardiovascular events in healthy men and women: A meta-analysis. JAMA J. Am. Med. Assoc. 2009, 301, 2024-2035. [CrossRef] [PubMed]

53. Strasser, B.; Burtscher, M. Survival of the fittest: VO2max, a key predictor of longevity? Front. Biosci. Landmark 2018, 23, 1505-1516. [CrossRef] [PubMed]

54. Bouchard, C. DNA Sequence Variations Contribute to Variability in Fitness and Trainability. Med. Sci. Sports Exerc. 2019, 51, 1781-1785. [CrossRef] [PubMed]

55. Joyner, M.J. Limits to the Evidence that DNA Sequence Differences Contribute to Variability in Fitness and Trainability. Med. Sci. Sports Exerc. 2019, 51, 1786-1789. [CrossRef] [PubMed]

56. Barnes, J.N.; Joyner, M.J. Physical activity and cardiovascular risk: 10 metabolic equivalents or bust. Mayo Clin. Proc. 2013, 88, 1353-1355. [CrossRef]

57. Baghai, T.C.; Binder, E.B.; Schule, C.; Salyakina, D.; Eser, D.; Lucae, S.; Zwanzger, P.; Haberger, C.; Zill, P.; Ising, M.; et al. Polymorphisms in the angiotensin-converting enzyme gene are associated with unipolar depression, ACE activity and hypercortisolism. Mol. Psychiatry 2006, 11, 1003-1015. [CrossRef]

58. Ma, F.; Yang, Y.; Li, X.; Zhou, F.; Gao, C.; Li, M.; Gao, L. The Association of Sport Performance with ACE and ACTN3 Genetic Polymorphisms: A Systematic Review and Meta-Analysis. PLoS ONE 2013, 8, e54685. [CrossRef]

59. Orysiak, J.; Zmijewski, P.; Klusiewicz, A.; Kaliszewski, P.; Malczewska-Lenczowska, J.; Gajewski, J.; Pokrywka, A. The association between ace gene variation and aerobic capacity in winter endurance disciplines. Biol. Sport 2013, 30, 249-253. [CrossRef]

60. Falahati, A.; Arazi, H. Association of ACE gene polymorphism with cardiovascular determinants of trained and untrained Iranian men. Genes Environ. 2019, 41, 8. [CrossRef]

61. Day, S.H.; Gohlke, P.; Dhamrait, S.S.; Williams, A.G. No correlation between circulating ACE activity and VO2max or mechanical efficiency in women. Eur. J. Appl. Physiol. 2007, 99, 11-18. [CrossRef]

62. Qi, Y.; Niu, W.; Zhu, T.; Zhou, W.; Qiu, C. Synergistic effect of the genetic polymorphisms of the renin-angiotensin- aldosterone system on high-altitude pulmonary edema: A study from Qinghai-Tibet altitude. Eur. J. Epidemiol. 2008, 23, 143-152. [CrossRef] [PubMed]

63. Jin, T.; Ren, Y.; Zhu, X.; Li, X.; Ouyang, Y.; He, X.; Zhang, Z.; Zhang, Y.; Kang, L.; Yuan, D. Angiotensin II Receptor 1 gene variants are associated with high-altitude pulmonary edema risk. Oncotarget 2016, 7, 77117-77123. [CrossRef] [PubMed]

64. Morrell, N.W.; Morris, K.G.; Stenmark, K.R. Role of angiotensin-converting enzyme and angiotensin II in development of hypoxic pulmonary hypertension. Am. J. Physiol. 1995, 269, H1186-H1194. [CrossRef] [PubMed]

65. Mahmood, S.S.; Pinsky, M.R. Heart-lung interactions during mechanical ventilation: The basics. Ann. Transl. Med. 2018, 6, 349. [CrossRef] [PubMed]

66. McPherron, A.C.; Lawler, A.M.; Lee, S.J. Regulation of skeletal muscle mass in mice by a new TGF- $\beta$ superfamily member. Nature 1997, 387, 83-90. [CrossRef] [PubMed]

67. Mondal, H.; Mishra, S.P. Effect of BMI, Body Fat Percentage and Fat Free Mass on Maximal Oxygen Consumption in Healthy Young Adults. J. Clin. Diagnostic Res. 2017, 11, CC17-CC20. [CrossRef]

68. Miyatani, M.; Kawano, H.; Masani, K.; Gando, Y.; Yamamoto, K.; Tanimoto, M.; Oh, T.; Usui, C.; Sanada, K.; Higuchi, M.; et al. Required muscle mass for preventing lifestyle-related diseases in Japanese women. BMC Public Health 2008, 8, 291. [CrossRef]

(C) 2020 by the authors. Licensee MDPI, Basel, Switzerland. This article is an open access article distributed under the terms and conditions of the Creative Commons Attribution (CC BY) license (http://creativecommons.org/licenses/by/4.0/). 